\title{
Development of a remote control rock bolting system for narrow seam hard rock mines
}

\author{
D. O'Connor ${ }^{1}$ and T. Sertic ${ }^{2}$ \\ ${ }^{1}$ MINOVA Africa (PTY) Ltd \\ 2DOKING Africa PTY Ltd
}

\begin{abstract}
An estimated 90 percent of South Africa's gold-bearing reefs are less than $1 \mathrm{~m}$ thick (Joughin 1976). A large mineral resource therefore lies in seams that are becoming increasingly uneconomic to extract because of the grade dilution caused by raising the mining height to suit currently available mechanized mining equipment (Harper 2008). A similar situation applies to platinum resources.
\end{abstract}

Historically in SA, mining of these narrow seams has been carried out by labour intensive methods, with little equipment beyond hand-operated rock drills. However, the arduous and hazardous work environment is becoming increasingly unattractive to both the workforce and mine operators. Globally, major mining companies are striving to increase safety by removing workers from the immediate vicinity of the operations and increasing productivity by better integration of the phases of the regular mining cycle to reduce cycle times (Lynch and White 2013). Attaining both objectives requires going beyond mechanization to high degrees of automation and/or remote control of equipment.

These factors present a challenge to South African mine operators and their equipment suppliers as mechanization of the narrow seam, hard rock mining environment has proven difficult with scant success (Pickering and Ebner 2006, and Harper 2008).

This paper describes the development of a semi-automated, remote controlled rock bolting system for hard rock mines with a mining height of between $0.9 \mathrm{~m}$ and $1.2 \mathrm{~m}$ (ULP Project). The rock bolting system required development of fully mechanized, remote controlled rock bolting rig, novel rock bolts and a pumpable, fast-acting resin grout to secure the bolts.

The introduction of systematic rock bolting has resulted in a decrease in rock-related accidents, but the many manual operations required in drill-steel and bolt handling in confined spaces and close proximity to high-powered equipment, has led to increased injuries (particularly hand injuries) to the rock bolting operators (Makusha 2015). Remotecontrol equipment has the potential to mitigate such injuries.

The rock bolter is one component of an equipment suite enabling full mechanization of rock breaking by blasting, clearing broken rock and rock support. Development started in 2012 and the bolting rig has been operating on a platinum mine since 2017. Deployment of further equipment suites is planned for 2019. 


\section{USER REQUIREMENT SPECIFICATIONS FOR THE EQUIPMENT}

For integration into the production targets of a fully mechanized mining operation, the key performance parameters for the bolting operation were set as:

- Nominal bolting speed of 8 minutes between collaring one hole to the collaring of the following hole;

- Total cycle time to drill 30 bolts (1.6 m drilling) not to exceed 2 hours; and

- Two $30 \mathrm{~m}$ panels to be drilled during one production shift.

In addition, there were comprehensive specifications on safety of operations and functionality in the envisaged low stope environment.

\section{PERFORMANCE AND OPERATIONAL REQUIREMENTS FOR THE ROCK BOLTS}

The standard support design for the stopes of the test area uses $1.6 \mathrm{~m}$ long deformed bar rock bolts, of either $20 \mathrm{~mm}$ or $18 \mathrm{~mm}$ diameter. The bolts themselves have nominal ultimate tensile strengths (UTS) of $170 \mathrm{kN}-200 \mathrm{kN}$ RSC (Ekusasa 2007) and must achieve a pull-out load of at least $100 \mathrm{KN}$ on $250 \mathrm{~mm}$ of resin bond in the short encapsulation pull test (SEPT) method generally used in the South African platinum mining industry. Most rock bolts used in this country are made from steel with UTS of $550 \mathrm{MPa}-600 \mathrm{MPa}$, while more advanced bolts use up to $850 \mathrm{MPa}$ steel.

Rock bolts used with the ULP project had to achieve at least the same performance as the conventional deformed bar rock bolts. Analysis of conventional rock bolting operations and rock bolts showed that they were not well suited for the required mechanized, automated bolting:

- The need to install $1.6 \mathrm{~m}$ long bolts in a mining height of $<1.2 \mathrm{~m}$, indicated that the drill steels would have to be coupled;

- The rock bolts themselves would also have to be coupled or flexible (cable anchors);

- Extraction of the coupled drill steel segments after drilling each hole and their storage so that they would be accessible for the next hole, appeared a difficult process to mechanise and automate;

- Installation of cable anchors is also a difficult process to fully mechanise and automate;

- Handling of conventional resin or grout capsules is equally difficult to mechanise and automate, because of their loss of rigidity. Although normally considered an aging issue, ( $\mathrm{O}^{\prime}$ Connor 2014), showed that resin capsules lose rigidity simply by being transported to a region of higher ambient pressure, such as in a deep mine; and

- A normal bolting cycle of drill, remove drill steels, insert grout capsules, insert bolt, spin bolt and then tighten bolt, is time consuming and presents several opportunities for failure (such as drill steels failing to extract), requiring human operator intervention.

An alternative was so-called self-drilling rock bolts (SDRs), also known as SDAs or self-drilling anchors. A SDR consists of a hollow steel rod (or coupled rods) with a sacrificial drill bit. The steel rod serves as the drill steel during the drilling phase. It is left in the drill hole and the central flushing hole is used to inject cement or resin grout to fill the external annulus between the steel rod and the rock, thereby fixing the rod into the hole. The rod then functions as a rock bolt. Use of SDRs is well established in the mining and construction industries (Minova-MAI 2017) for rock bolting in very unstable ground, where the drill holes close between withdrawal of the drill rod and insertion of a rock bolt.

SDRs are made of high-grade steel as they need to withstand the stresses of drilling, then the design loads in their service as rock bolts. Typical steel specification of an SDR is UTS of $600 \mathrm{MPa}-860 \mathrm{MPa}$ (Minova-MAI 2017). The external surface is deformed into a continuous coarse thread profile, for example a rope thread with pitch of $12 \mathrm{~mm}$ and depth of $4.8 \mathrm{~mm}$. The threaded profile increases axial 
shear resistance between the SDR and the surrounding grout, and can be used to attach accessories such as the sacrificial drill bit, centralisers and couplings.

Use of commonly-available SDRs was considered, but they proved to be unsuitable. Conventional SDRs use external sleeve couplings to couple segments together. The sleeve couplings have substantially larger diameter than the SDR itself, forcing the use of a larger bit and creating a large annulus around the bolt to filled by the grout. Typical data for a $25 \mathrm{~mm}$ diameter SDR system is presented in Table I, (Minova-MAI 2017).

\begin{tabular}{|l|l|l|l|l|}
\hline \multicolumn{6}{|l|}{ Table I. 25 mm diameter grouted conventional SDR system } \\
\hline $\begin{array}{l}\text { Bolt } \\
\text { diameter } \\
(\mathrm{mm})\end{array}$ & $\begin{array}{l}\text { Bolt UTS } \\
(\mathrm{kN})\end{array}$ & $\begin{array}{l}\text { Coupling } \\
\text { diameter } \\
(\mathrm{mm})\end{array}$ & $\begin{array}{l}\text { Drill bit } \\
\text { diameter }(\mathrm{mm})\end{array}$ & Grout volume for 1.6 m bolt $(\mathrm{l})$ \\
\hline 25 & 150 & 33.7 & 42 & 1.43 \\
\hline
\end{tabular}

Sleeve couplings are also expensive. In the mainstream use of SDRs, the rods are typically $2 \mathrm{~m}-4 \mathrm{~m}$ long, so few couplings are needed to make up a drill string. However, in this project, the maximum length of the SDR segments was limited to $400 \mathrm{~mm}$, so three couplings are required for a $1.6 \mathrm{~m}$ bolt.

An alternative type of SDR was sought. An unusual SDR rod manufactured in South Africa, which is termed NCA steel, was found, and consists of a $25 \mathrm{~mm}$ diameter drill steel with external rebar-type deformations. It was manufactured on a small scale for specialised rehabilitation of concrete structures. The central flushing hole is only $11 \mathrm{~mm}$ in diameter, leaving a cross-sectional area of $396 \mathrm{~mm}^{2}$ - more than that of the $20 \mathrm{~mm}$ conventional solid rock bolt. NCA steel had not been coupled before. It has a minimum tensile strength of $940 \mathrm{MPa}$ (ArcelorMittal 2017). The high strength combined with the larger cross-sectional area allowed design of a taper-threaded internal coupling (See Figure 1). This avoided the hole diameter increase associated with conventional sleeve couplings.

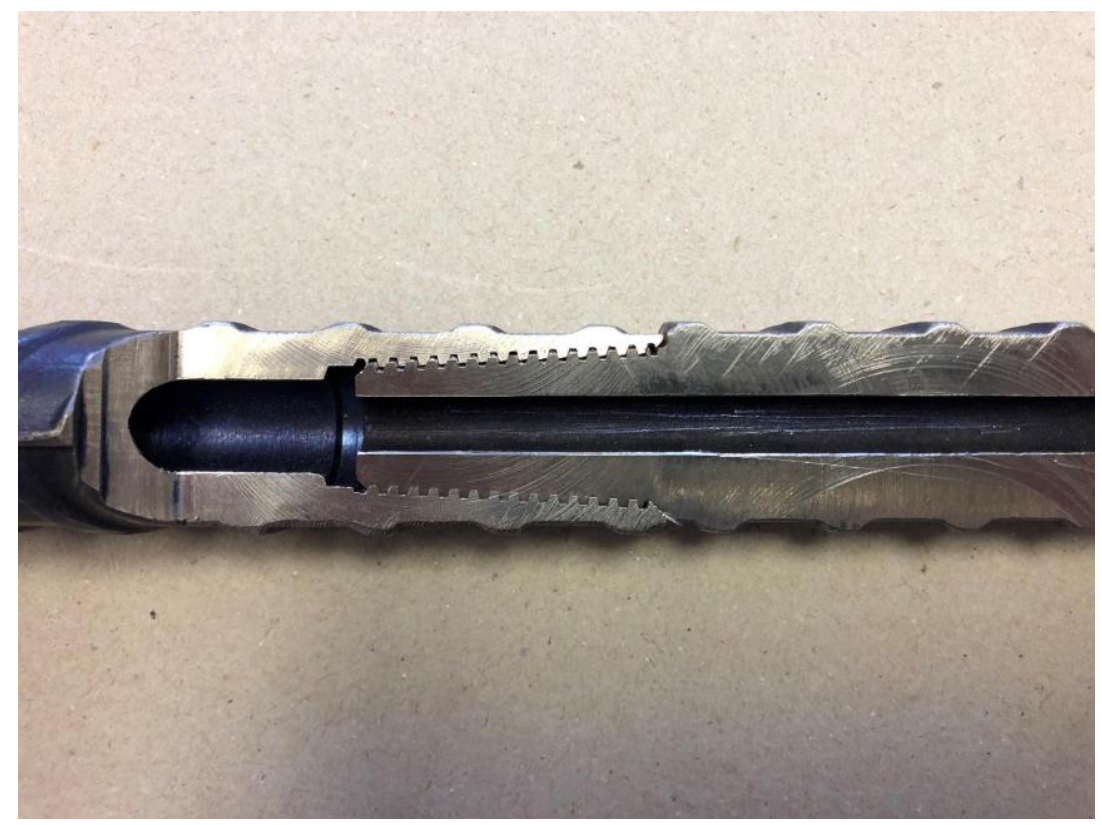

Figure 1. Cutaway view of taper-threaded internal coupling

Prototype NCA rods with the internal taper-threaded couplings were made up and tensile tested at a SANAS-accredited test facility. Minimum breaking load was $176 \mathrm{kN}$. This qualified the coupled NCA steel as strong enough for the SDR component of the rock bolting system. 


\section{DRILLING METHOD - PERCUSSION OR ROTARY?}

Early in the project, a decision had to be taken on the drilling method to be used: either percussion or rotary, as the choice was fundamental to the design and equipping of the rig as well as to the configuration of the rock bolts and drill rods

Compressive strengths (UCS) of hanging wall rocks in South Africa's gold and platinum mines are in the range of $120 \mathrm{MPa}$ to over $250 \mathrm{MPa}$. Conventional production drilling in such rock is by percussion drills (Pickering and Ebner 2001). Limited data was available on the use of rotary drilling in hard rock. In 2003, one of the authors had tested rotary drilling in the hanging wall of a platinum mine, using a hand-held bolter (Turbo-bolter) and found that it was a feasible method.

Comparison of rotary vs percussion drilling was carried out and the findings are summarized in Table II.

\begin{tabular}{|l|l|l|}
\hline \multirow{2}{*}{ Table II. Comparison of rotary versus percussion drilling } \\
\cline { 2 - 3 } & \multicolumn{2}{|c|}{ Drilling Technology } \\
\hline Technology risk & $\begin{array}{l}\text { High-limited experience and } \\
\text { data available in hard rock }\end{array}$ & $\begin{array}{l}\text { Percussion } \\
\text { technology in hard rock }\end{array}$ \\
\hline Power source & $\begin{array}{l}\text { Electric: suitable for battery } \\
\text { supply }\end{array}$ & $\begin{array}{l}\text { Hydraulic: large power pack } \\
\text { required; }\end{array}$ \\
\hline $\begin{array}{l}\text { Vibration levels and impact on } \\
\text { surrounding equipment }\end{array}$ & $\begin{array}{l}\text { Low; low impact on } \\
\text { surrounding equipment }\end{array}$ & $\begin{array}{l}\text { Very high; surrounding } \\
\text { equipment must be rugged }\end{array}$ \\
\hline Sound level & Lower - can be made < $85 \mathrm{dBa}$ & High to very high $(>95 \mathrm{dBa})$ \\
\hline Drifter length & Can be made compact & Long - typically over $600 \mathrm{~mm}$ \\
\hline
\end{tabular}

The comparison showed that rotary drilling was conceptually more suited to integration into the compact, low-height bolter rig, but that actual drilling capability and equipment specification was still unknown.

To confirm the feasibility of routine rotary drilling in hard rock, and to gather data for equipment design, an instrumented drilling test rig was built (See Figure 2).

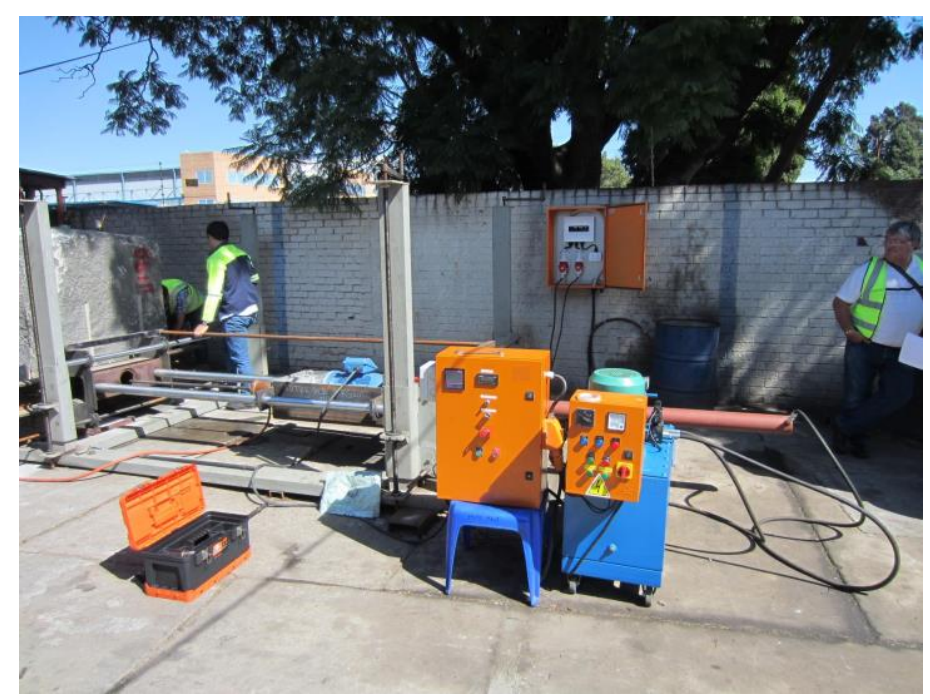

Figure 2. General view of drilling test rig 
The test rig enabled drilling with controllable thrust and rotation speed (rpm), while measuring instantaneous penetration rate and torque. Norite (UCS $200 \mathrm{MPa}$ ) was used for the drilling trials.

NCA drill rods were made up with shaped heads, into which tungsten carbide (TC) inserts for were brazed (See Figure 3). The TC inserts were $30 \mathrm{~mm}$ wide, giving holes with $5 \mathrm{~mm}$ diameter difference over the $25 \mathrm{~mm}$ diameter NCA drill rods, for flushing of the drill chippings. Water was used for flushing.

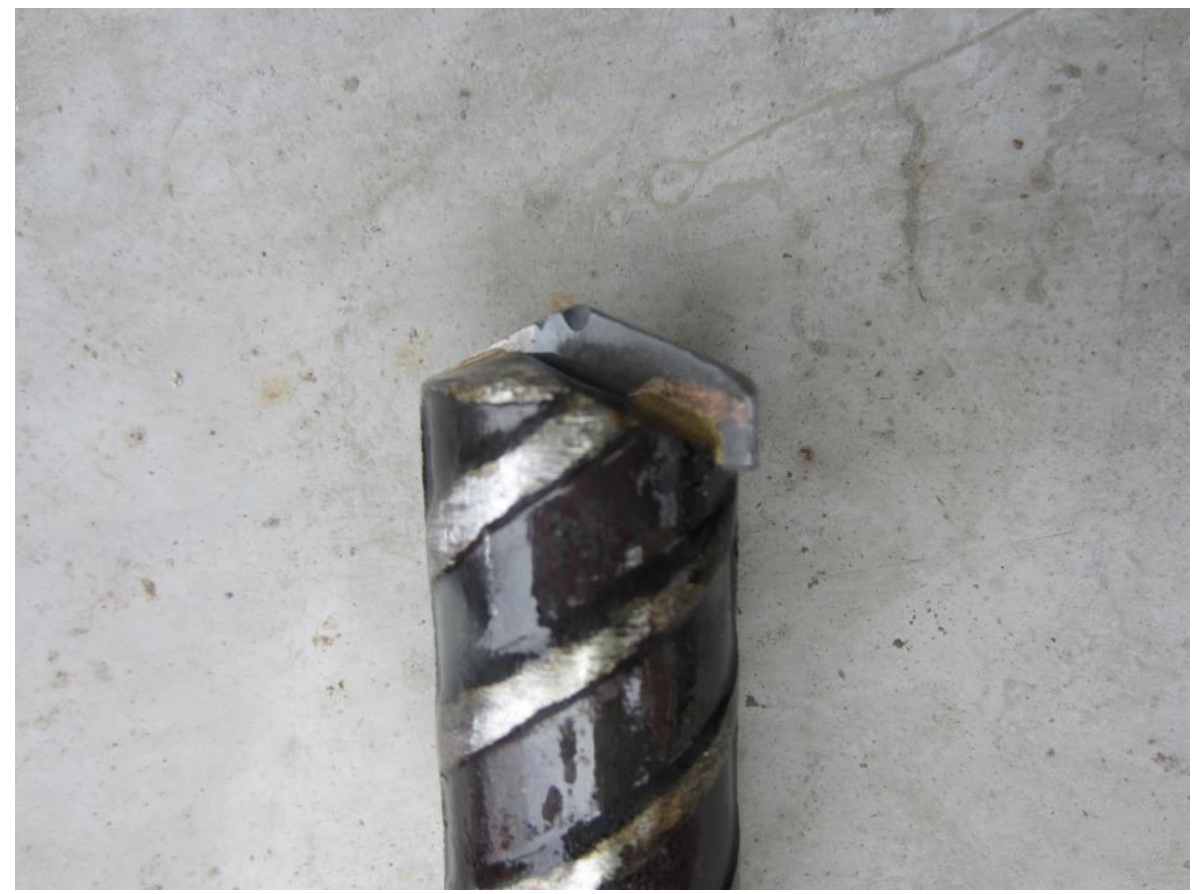

Figure 3. Drill bits for rotary drilling

Using the rig, 56 holes were drilled between February and April 2013. This demonstrated that:

- Rotary drilling of the norite with standard TC borers was feasible. Penetration rates exceeding $1.5 \mathrm{~m} /$ minute were consistently achieved and the TC inserts lasted the required $1.6 \mathrm{~m}$ of drilling depth (See Figure 4); and

- The NCA steel and the internal taper-threaded couplings were successful as drill rods. 


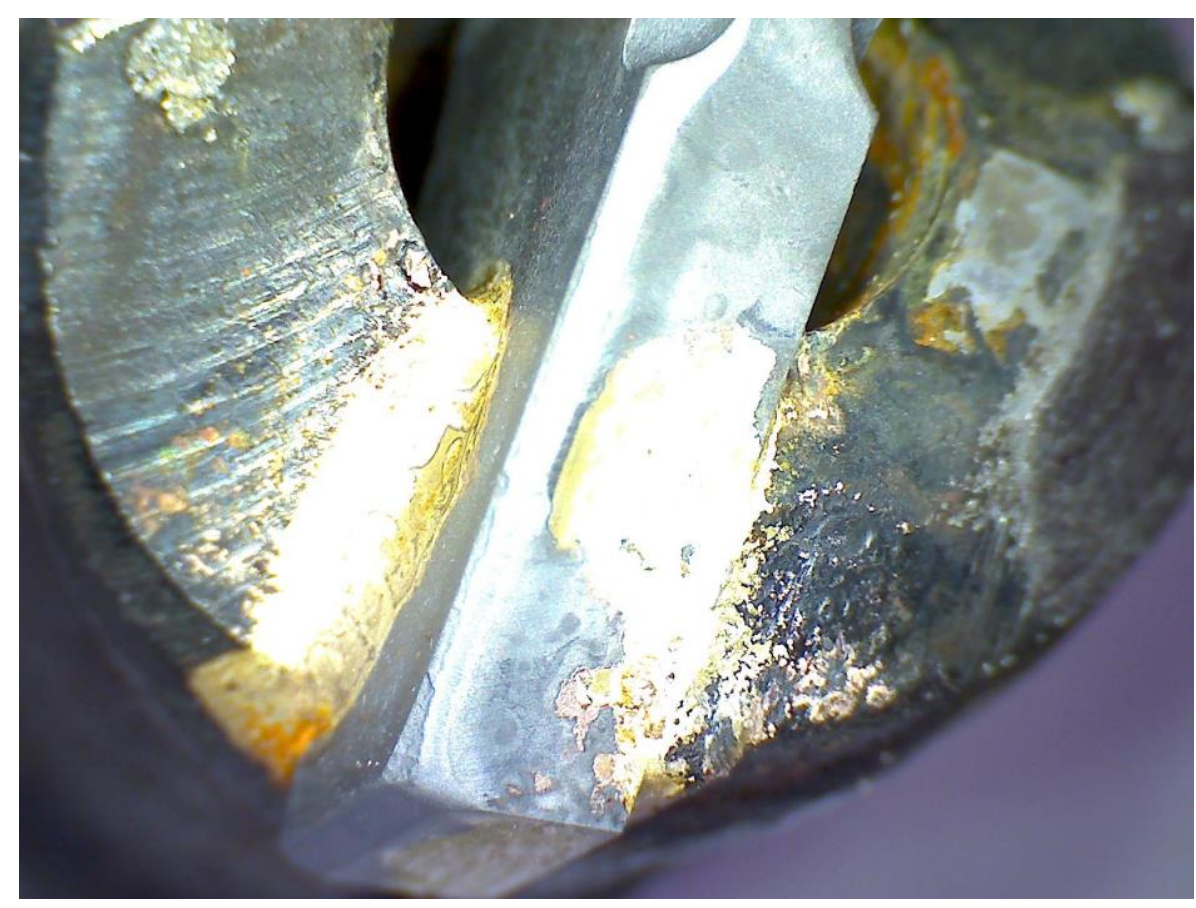

Figure 4. Enlarged view of drill bit after drilling a $1.6 \mathrm{~m}$ hole

Extensive data on the penetration rate versus thrust and torque were obtained for the design of the drilling head on the bolter and for setting operating parameters. It was found that the best results were obtained at high rotation rate (700 rpm) and thrust in the range $40 \mathrm{KN}-50 \mathrm{KN} \mathrm{O}^{\prime}$ Connor (2013). A bilinear regression calculation on drill penetration rate versus rpm and thrust in the ranges tested gave:

$$
\text { Penetration rate }(\mathrm{mm} / \text { minute })=\quad 1.29 \mathrm{RPM}+4.44 \text { Thrust }(\mathrm{KN}) \text {. }
$$

In 2018 a further series of drilling tests was carried out using an actual bolter, drilling into a large block of norite set up in a surface workshop. The results are reported in Appendix 1.

\section{GROUTING OF THE SELF-DRILLING ROCK BOLTS}

The user requirement for short hole-cycle time required a fast-setting grout. The bolter rig needed to move on to the following hole within seconds of completing an installation, while the grout had to build strength rapidly to provide effective support. Speed had to be balanced with a working time long enough for the grout to be pumped through the bolt and fill the hole before setting.

Conventional bolted stope support uses 30 second or 60 second set-time resin capsules Maepa and Zvarivadza (2017), and these formed the benchmark for performance of the pumped grout system. At the time of development $(2012-2104)$ no cement grouts were available that met these requirements. A two-component resin grout had been developed Richter (2005) for use with SDRs and it was decided to test this material. The resin grout is an organo-silicate system, supplied as two liquids with viscosities in the range $150 \mathrm{mPa}-\mathrm{s}-300 \mathrm{mPa}$-s Minova Carbotech (2017). When the two components are vigorously mixed, a two-stage chemical reaction takes place. In the first stage, the mixture thickens and becomes thixotropic, but is still pumpable. This prevents the material from flowing out of the hole and ensures that the annulus around the bolt is completely filled. In the second stage, polymerization of the organic phase and precipitation of solid silica takes place, resulting in a solid grout. 
The resin grout first used had an initial hardening time (the time at which the bolter rig could release the bolt) of 60 seconds and reached full strength in 6 hours. Discussions with the manufacturer prompted further development and these times have now been shortened to 20 seconds and minutes respectively. Variants of the same resin grout are being used in automated rock bolting developments elsewhere in the world Bray and Johnsson (2019).

The fast reaction time of the resin requires near in situ mixing. For this, single-use static mixers are incorporated into the base of each bolt. Workshop trials were carried out to determine the length of static mixer required to produce complete mixing; the trials showed that $100 \mathrm{~mm}$ of the X-type static mixer were adequate (See Figure 5).

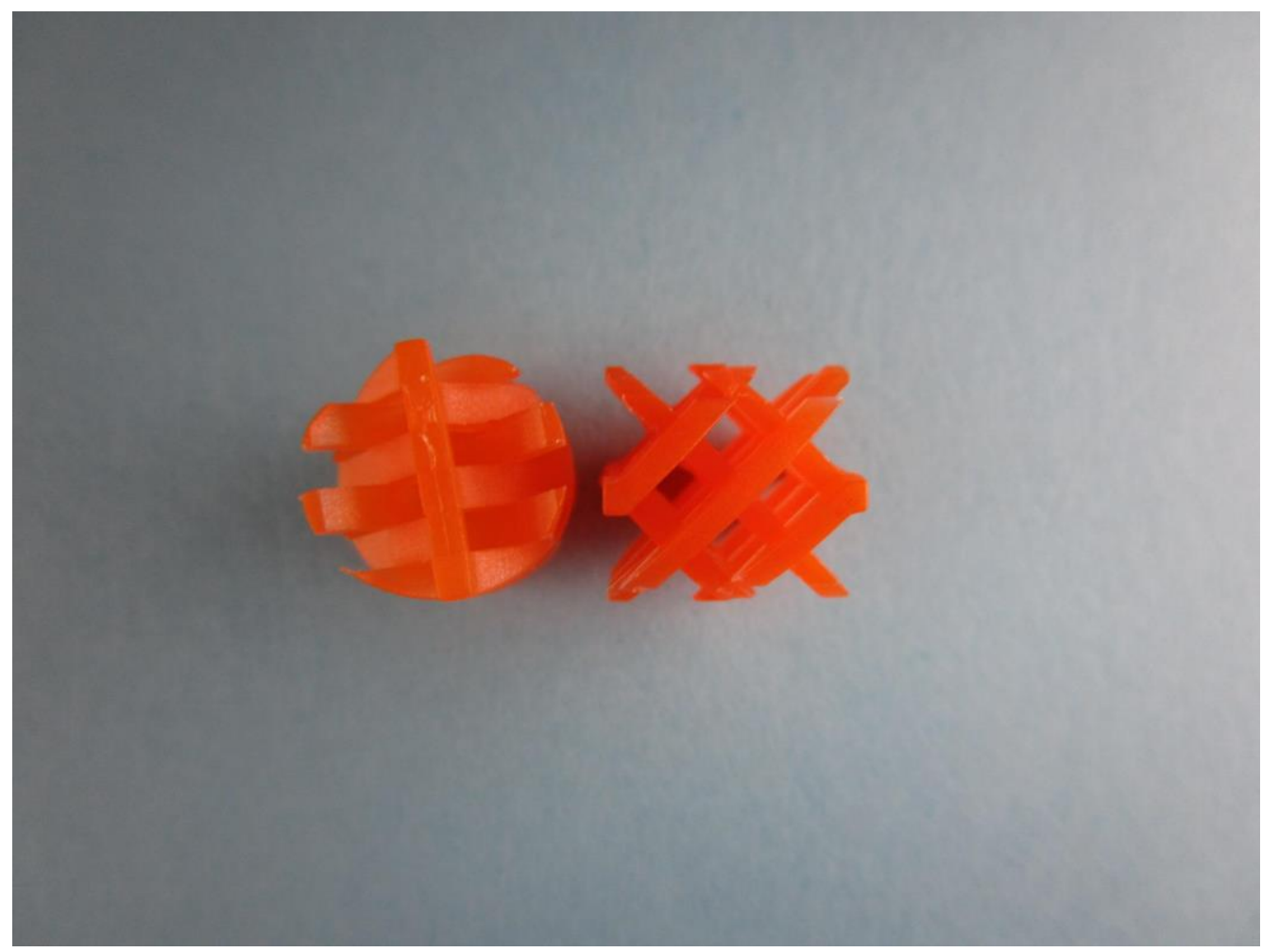

Figure 5. X-type static mixer elements

Properties and performance of the resin grout used in 2018 are shown in Table III.

\begin{tabular}{|l|l|l|l|}
\hline \multicolumn{4}{|l|}{ Table III. Resin grout properties } \\
\hline At $25^{\circ} \mathrm{C}$ & Component A & Component B & Mixed grout \\
\hline Major constituent & Sodium Silicate & Poly-isocyanate & \\
\hline Viscosity (mPa-s) & $200-300$ & $140-240$ & \\
\hline Relative density & 1.43 & 1.16 & \\
\hline Initial thickening (s) & & & $3-10$ \\
\hline Initial set (s) & & & $20-100$ \\
\hline $\begin{array}{l}\text { Shore D hardness at 30 } \\
\text { minutes }\end{array}$ & & 60 \\
\hline
\end{tabular}




\section{TESTING AND QUALIFICATION}

\section{Field short encapsulation pull testing}

Individual segments of the SDRs were installed in $250 \mathrm{~mm}$ deep holes drilled in the hanging wall of a platinum mine near Rustenburg, in July 2015. The holes were $30 \mathrm{~mm}$ diameter and pre-drilled using a conventional roof bolter. After installation, the bolts were pulled with a hand-operated hydraulic ram at varying times after installation. The results are shown in Table IV.

\begin{tabular}{|c|c|c|c|}
\hline \multicolumn{4}{|c|}{ Table IV. Underground SEPT results } \\
\hline Hole No & Cure time & $\begin{array}{l}\text { Maximum } \\
\text { load }\end{array}$ & Notes \\
\hline & (minutes) & $(\mathrm{KN})$ & \\
\hline 3 & 90 & 120 & 1 \\
\hline $3 \mathrm{~B}$ & 1440 & 150 & 2 \\
\hline 4 & 1440 & 150 & 2 \\
\hline 5 & 1440 & 125 & 2 \\
\hline 6 & 1440 & 150 & 2 \\
\hline 7 & 1440 & 150 & 2 \\
\hline 7 & 1440 & 160 & 2 \\
\hline 15 & 1440 & 150 & 2 \\
\hline 16 & 1440 & 110 & \\
\hline 17 & 1440 & 100 & \\
\hline 18 & 1440 & 60 & \\
\hline 19 & 1440 & 75 & 1 \\
\hline 20 & 1440 & 75 & 2 \\
\hline $1 \mathrm{~A}$ & 56 & 40 & 2 \\
\hline $2 \mathrm{~A}$ & 63 & 200 & 2 \\
\hline $3 \mathrm{~A}$ & 76 & 170 & 2 \\
\hline $4 \mathrm{~A}$ & 88 & 230 & 2 \\
\hline $5 \mathrm{~A}$ & 92 & 160 & 2 \\
\hline $6 \mathrm{~A}$ & 98 & 200 & 2 \\
\hline $7 \mathrm{~A}$ & 102 & 200 & 2 \\
\hline $8 \mathrm{~A}$ & 107 & 200 & 2 \\
\hline $10 \mathrm{~A}$ & 51 & 110 & 3 \\
\hline $11 \mathrm{~A}$ & 42 & 200 & 2 \\
\hline
\end{tabular}

Explanation of notes: -

1) Installation failure

2) Test stopped before failure

3) Rock failed.

- Salient outcomes from the tests were that there were many aspects of the installation and testing process that had to be learned and mastered before consistent results were achieved. Both the resin bond and the bolts themselves achieved the design loads. 
Proof of concept trials (2015)

The complete rock bolting system was subjected to a proof of concept (POC) trial at the same platinum mine. After initial development of operating procedures, measurements were made of cycle times. A typical cycle is shown in Table V.

Table V. Drilling and grouting cycle times

\begin{tabular}{|l|l|l|l|}
\hline Activity & Start time & End time & Total time \\
\hline Move machine & 0 & 0 & $00: 00: 00$ \\
\hline Line up booms & $11: 33: 55$ & $11: 34: 49$ & $00: 00: 54$ \\
\hline SDR Rod Installation & & & \\
\hline Load 1st SDR & $11: 35: 22$ & $11: 35: 52$ & $00: 00: 30$ \\
\hline Drill 1st SDR & $11: 35: 52$ & $11: 37: 00$ & $00: 01: 08$ \\
\hline Load 2nd SDR & $11: 37: 00$ & $11: 37: 15$ & $00: 00: 15$ \\
\hline Drill 2nd SDR & $11: 37: 15$ & $11: 38: 57$ & $00: 01: 42$ \\
\hline Load 3rd SDR & $11: 38: 57$ & $11: 39: 15$ & $00: 00: 18$ \\
\hline Drill 3rd SDR & $11: 39: 15$ & $11: 41: 31$ & $00: 02: 16$ \\
\hline Load 4th SDR & $11: 41: 31$ & $11: 41: 48$ & $00: 00: 17$ \\
\hline Drill 4th SDR & $11: 41: 48$ & $11: 43: 34$ & $00: 01: 46$ \\
\hline Resin injection & $11: 43: 34$ & $11: 43: 44$ & $00: 00: 10$ \\
\hline Total time to install SDR & & & $00: 08: 22$ \\
\hline
\end{tabular}

The POC trial showed that ULP bolting system was able to achieve the user specification of installing one SDR in less than 8 minutes.

Excluding downtime and externally caused delays, the drilling times achieved were between 06:49 and 07:22 minutes.

\section{CURRENT STATUS}

The system has been in use at a platinum mine on the Eastern Limb of the Bushveld Complex since 2017. Since 2015 the bolter rig has seen significant evolution on the basis of operational experience. Figure 6 and Figure 7 show the 2014 and 2019 versions respectively - the later version is more compact, lighter and provides easier access for maintenance. The two drilling booms each incorporate staking rods that stabilise the booms during drilling, ensuring consistent alignment between the SDR segments and between the base of the drill string and the drilling head/resin injection ports.

The rock bolter is part of an equipment suite. The stope layout was re-designed to be compatible with the strengths and limitations of the equipment suite. The bolter is steered manually (using radio remote control) when moving between stope panels. The layout avoids the need to cross obstructions such as gullies. 


\section{CONCLUSION}

A multi-year development programme involving users and equipment suppliers has resulted in a working system for automated and remote-controlled rock bolting in hard-rock mines with tabular stopes less than $1 \mathrm{~m}$ high. In the short term, this will result in improvements in the productivity and safety of existing operations, chiefly located in South Africa. In the longer term, the suite of ultra lowprofile mining equipment may allow some narrow orebodies, currently considered as uneconomic to mine, to be re-classified as mineral reserves.

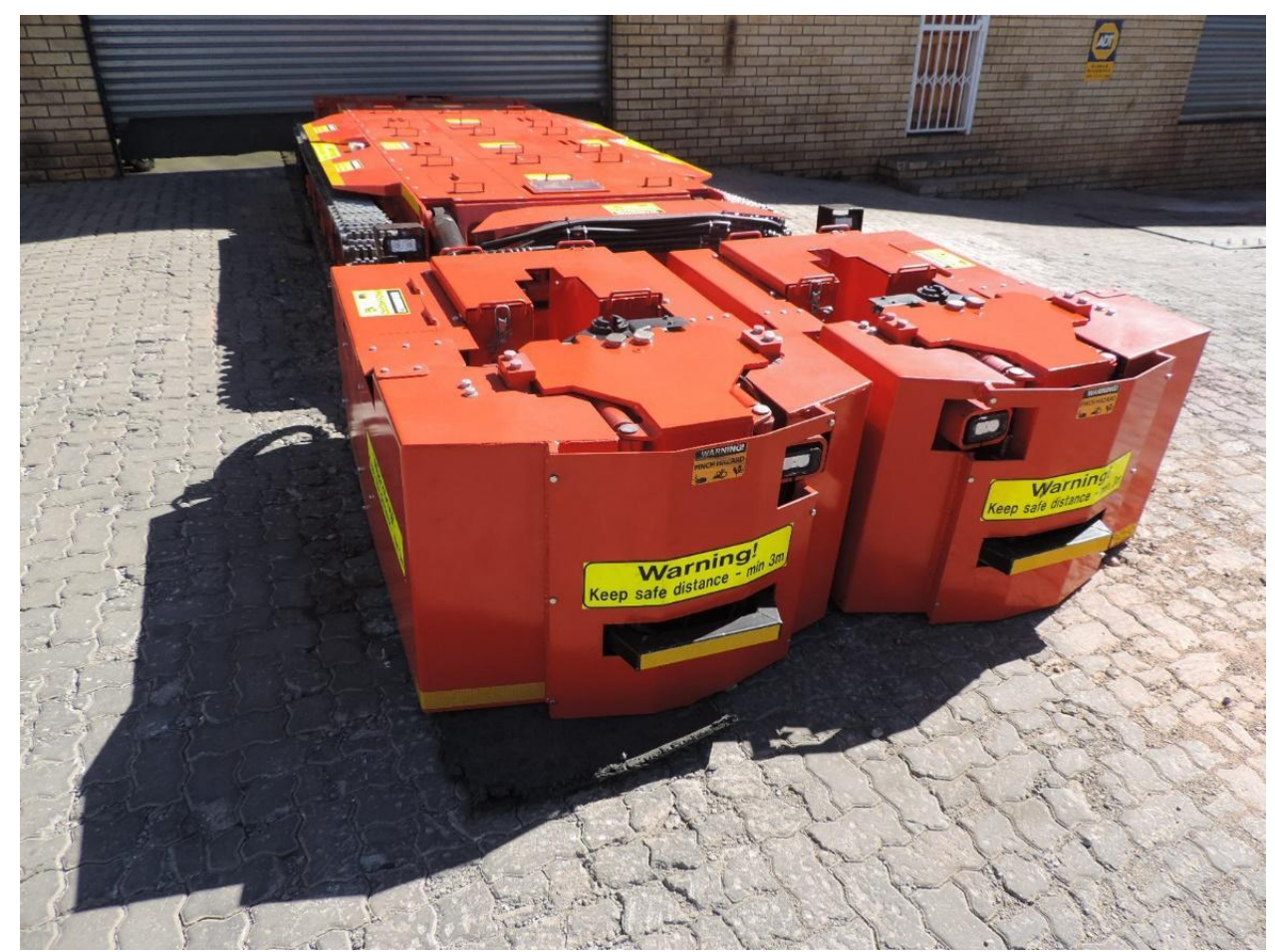

Figure 6. 2014 version of bolter rig

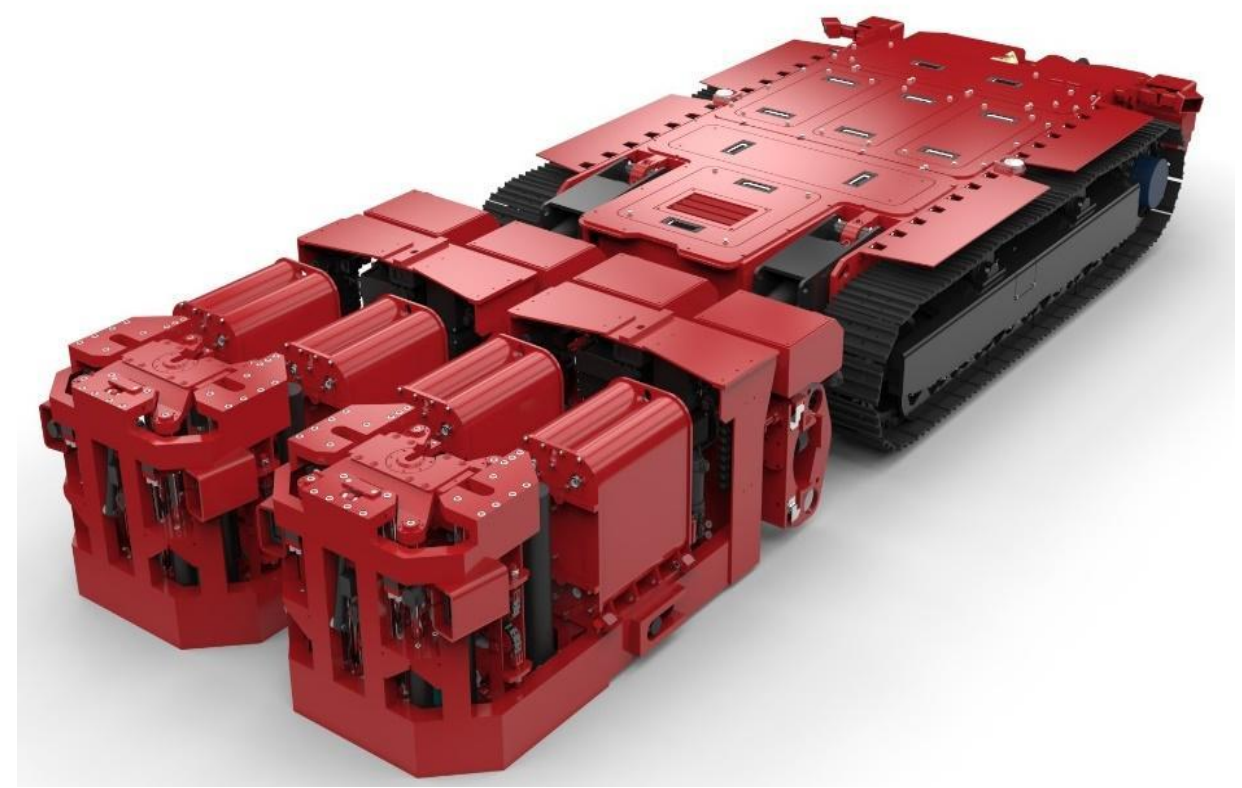




\section{APPENDIX 1}

Figure 7. 2019 version of the bolter rig

Second series of rotary drilling trials

In December 2018, a second rotary drilling trials programme was carried out as part of ongoing system improvement. This programme made use of an actual bolter to carry out the drilling, so the results could therefore be applied directly to optimize drilling parameters and practice.

The holes were drilled into a large block of quarried norite supported on a frame to simulate the hanging wall of a stope (See Figure A1.1).

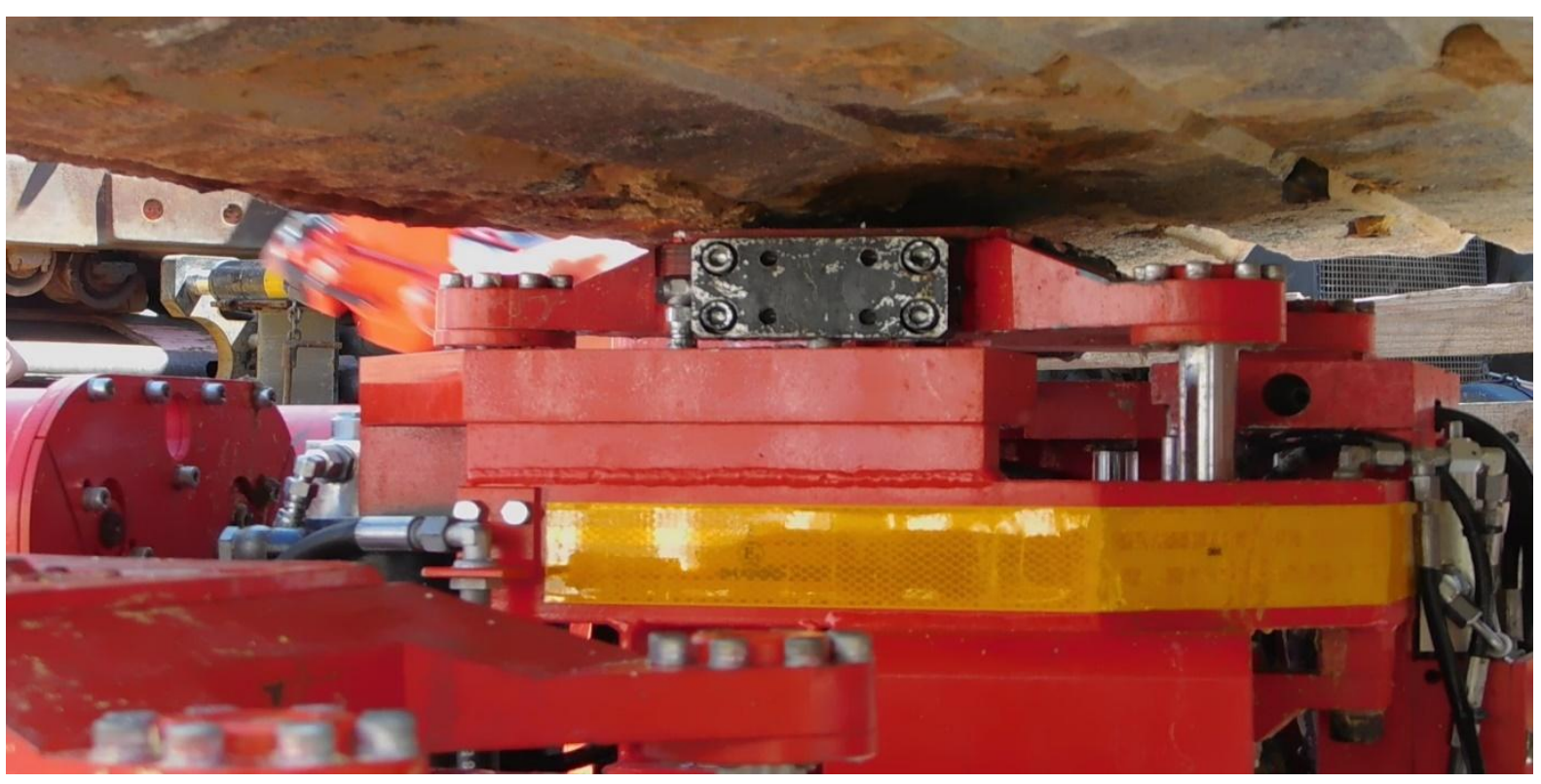

Figure A1.1. ULPSR 002 in drilling position

Two series of tests were carried out, one with soft collaring of the bit and one without. Soft collaring used a slow approach of the bit to the rock face and a gradual ramp-up of thrust and rotation speed. It was intended to reduce the likelihood of the bit shattering on contact with the rock.

The tests measured drilling time against rotation speed (rpm) at different thrust settings. Drill bit condition was recorded after each hole.

The results are summarized in Figures A1.1 and A1.2. 


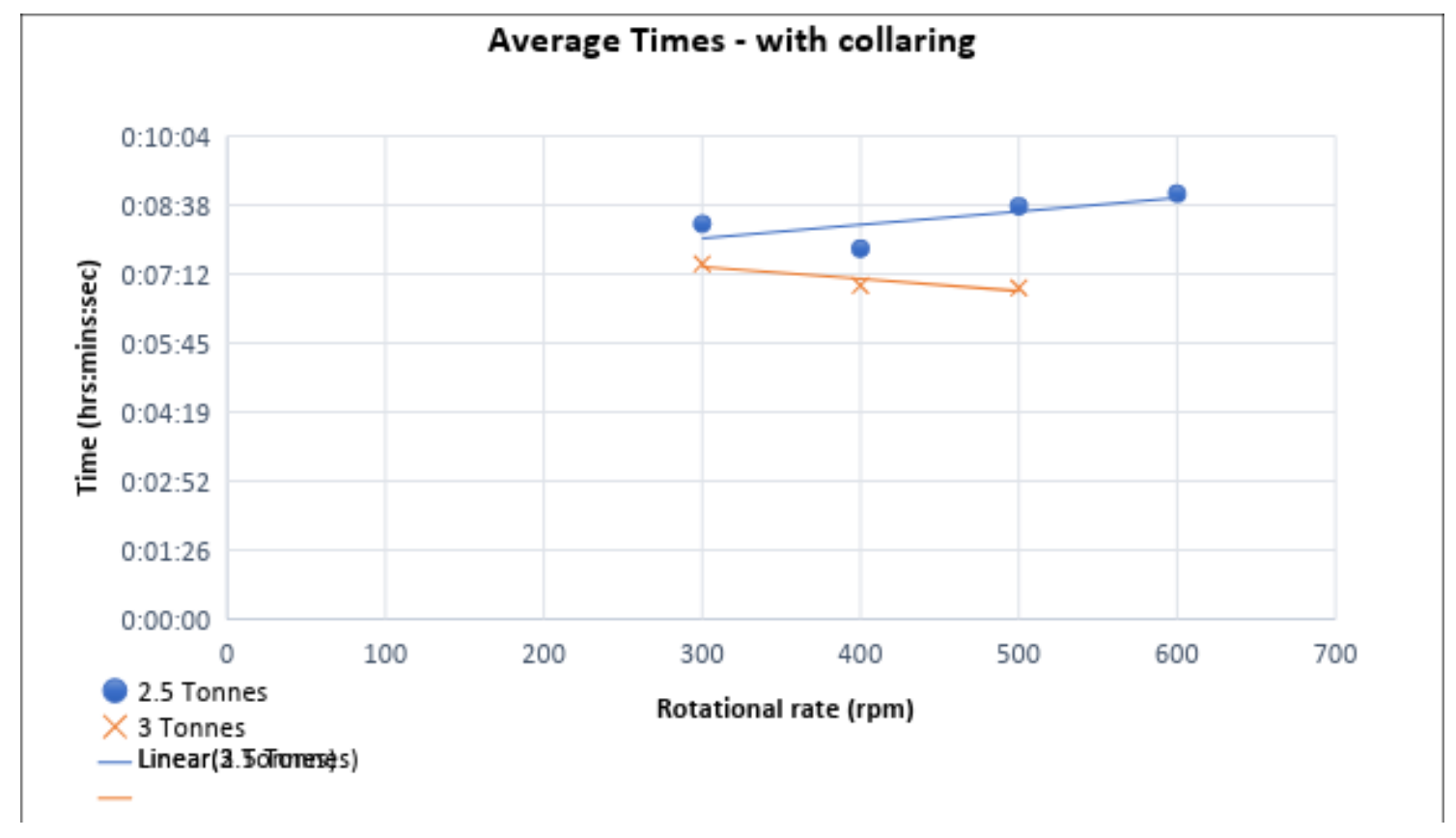

Figure A1.1. Average times with collaring

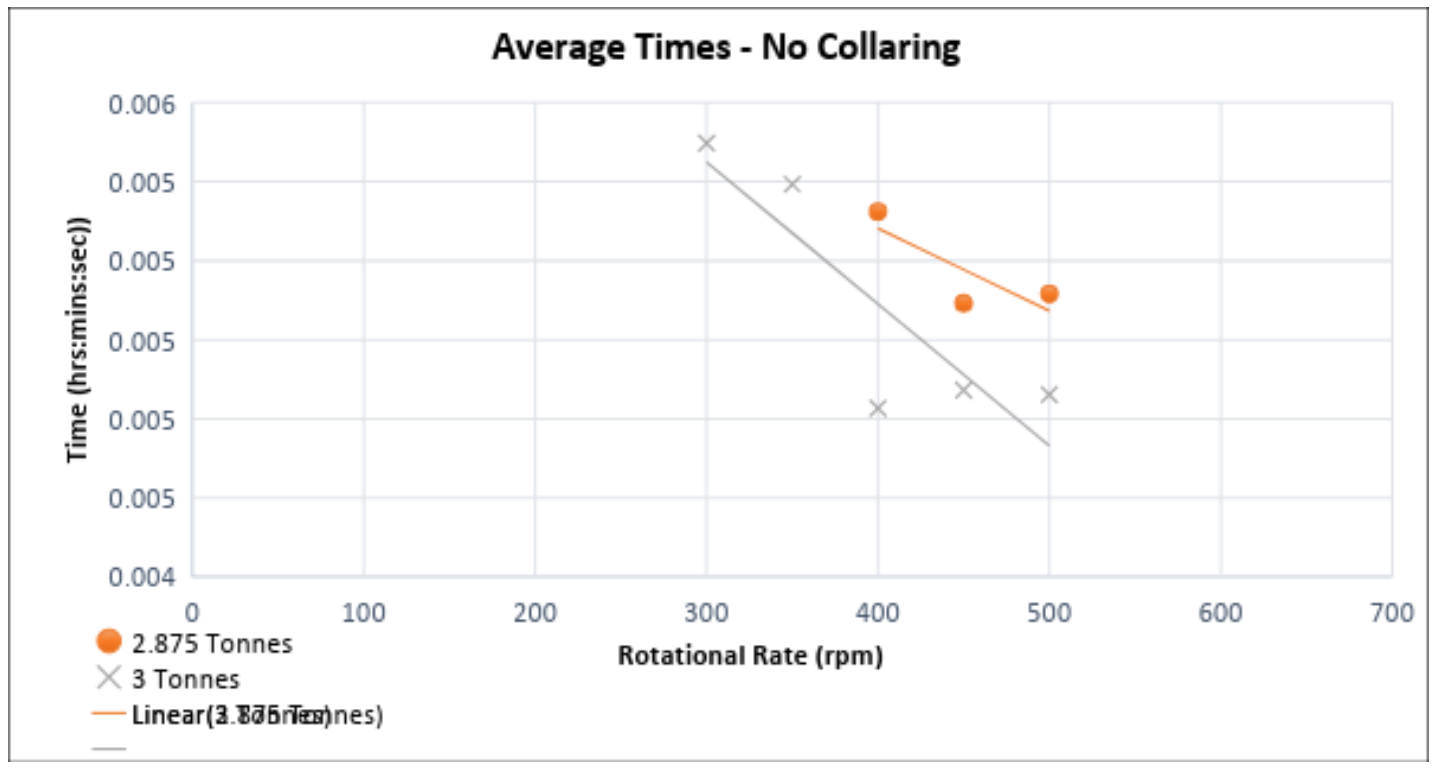

Figure A1.2. Average times without collaring

\section{Findings}

- Increasing thrust force produces a reduction in drilling time, but when thrust exceeded 3 tonnes $(30 \mathrm{KN})$, there was a heightened risk of premature bit failure.

- For each thrust setting, there was an indication of an optimal rotation rate (rpm). When rotation rate exceeded $600 \mathrm{rpm}$, there was heightened risk of premature bit failure.

- There was no significant difference in time when drilling with or without soft collaring.

- The drill bits are capable of drilling at least $1.6 \mathrm{~m}$ into the hard norite, provided that thrust was limited to 3 tonnes $(30 \mathrm{KN})$ with a rotation rate of less than $600 \mathrm{rpm}$. 


\section{References:}

ARCELORMitTAl 2017. Material Test Certificates, Arcelor-Mittal, Vereeniging, South Africa, 2017.

BRAY, P. AND JOHNSSON, A. 2019. Case study: LKAB Malmberget, self-drilling anchors and pumpable resin. Paper submitted for publication at DeepMine 2019, SAIMM, Johannesburg, 2019.

MAKUSHA, G., 2015. Personal communication.

HARPER, G.S. 2008. Nederburg Miner. Presented at Narrow Vein and Reef Symposium, SAIMM, Johannesburg 2008. pp. 2 - 4.

HARPER, G.S. 2008. Nederburg Miner. Presented at Narrow Vein and Reef Symposium, SAIMM, Johannesburg 2008. Pg 4.

LYNCH, M. AND WHITE, B. 2013. Brave new world of autonomous mining systems. World Gold Conference Brisbane, AusIMM, Melbourne, 2013. Pg 1.

MAEPA, T. AND ZVARIVADZA, T. 2017. Installation of resin-grouted rockbolts in hard-rock mining: challenges and solutions for improved safety. JSAIMM, vol 117, April 2017, pg 331.

MINOVA-MAI, 2017. Self-drilling systems product catalogue, Minova-MAI, Austria, 2017, pp 3-10.

MINOVA-MAI, 2017. Self-drilling systems product catalogue, Minova-MAI, Austria, 2017, pp 16.

MINOVA CARBOTECH, 2017. Carbothix 150709 Technical Data Sheet. Minova Carbotech, Essen, 2017.

JOUGHIN, N.C. 1976. Potential for mechanization in gold mines. JSAIMM, Johannesburg, January 1976.

O'CONNOR, D. 2014. Effect of atmospheric pressure on resin capsule rigidity. Presented at SANIRE Coalfields Branch Symposium, November 2014.

O'CONNOR, D. 2013. Interim report on rotary drilling trials in norite. Minova Africa (Pty) Ltd internal report, Johannesburg, 2013.

PICKERING, R. AND EBNER, B. 2001. Hard rock cutting and development of a continuous mining machine for narrow platinum reefs. $6^{\text {th }}$ International Symposium on mine mechanisation and automation. SAIMM, Johannesburg, 2001. Pg 1.

RICHTER, A. 2005. A method for embedding rock anchors. Australian Patent Office, Application No. 2005297473 B2, 2005.

RSC EKUSASA. Product datasheet, RSC Ekusasa Mining, Johannesburg, 2007. pg 3.

\section{Donald O'Connor}

Minova

After obtaining my B.Sc Hons in Geophysics and Mathematics, I started in the mining industry on Western Deep Levels Gold Mine in 1978, working on mine seismicity and numerical modelling. Since 1982 I have been active in the development, manufacture and application of products and systems used for rock support, including resin and cement grouts, rock bolts, drilling equipment and measuring systems and even explosives During this period I have been at various times the CEO of Stratabolt 
Products, Dantex Explosives, Fosroc Stratabolt and Minova Africa. My present role is product and systems development for Minova Africa and it was in that role that I worked on the development described in our paper.

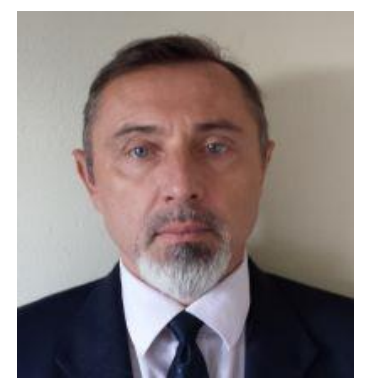

\section{Tom Sertic}

Managing Director

Doking Africa Pty Ltd

Obtained BSC degree in mechanical engineering in 1986. I have more than 33 years of experience in project management from which 28 years relates to the mining industry including design and construction of both open cast and underground mines. I have joined DOK-ING in 2003 and was cofounder of DOKING AFRICA. From 2009 to date involved in development of electrically powered Ultra Low Profile fleet consisting of Dozer, Drill rig, Support Rig and Sweeper. Last 17 years I am extensively promoting utilisation of Extra Low Profile and Ultra Low Profile mining equipment. My duties also include management of maintenance function in the mines utilising DOK-ING equipment and customer relationship with major clients and keeping them abreast with the latest development in the application of the electrically powered equipment in the mining industry. 